\title{
Znaczenie sektora ICT w państwach Unii Europejskiej - analiza klastrowa
}

\author{
Importance of ICT sector in the European Union countries - cluster analysis
}

\section{Wprowadzenie}

Technologie informacyjno-komunikacyjne (ICT) uznawane są za nieodłączny element życia współczesnego społeczeństwa i pełnią w nim istotną rolę w każdej dziedzinie. Zgodnie z definicją przyjętą w raporcie Perspektywy rozwoju polskiej branży ICT do roku 2025 (2017) ICT należą do rodziny technologii gromadzących, przetwarzających i przesyłających informacje $\mathrm{w}$ formie elektronicznej. Istnieje również węższe pojęcie - technologie informatyczne (IT), które odnosi się do technologii związanych z oprogramowaniami i komputerami, nie dotyczy natomiast technologii komunikacyjnych i sieciowych. Ich rozwój sprawia, że stają się one coraz bardziej spójne, jak również są determinantą intensyfikacji rozwoju społecznego, cywilizacyjnego oraz gospodarczego. Działania związane $\mathrm{z}$ technologiami informacyjno-komunikacyjnymi występują w ramach sektora ICT. W nim zachodzą wszelkie działania związane z tworzeniem urządzeń informatycznych i komunikacyjnych oraz usługi im towarzyszące (Perspektywy, 2017). Podział sektora na obszar produkcyjny i usługowy został zawarty w części metodycznej opracowania. Sektor ICT uznawany jest za najbardziej innowacyjny i mający istotne znaczenie w poprawie efektywności oraz działaniach innych sektorów gospodarki. Jest jednym z najmłodszych rynków i jednocześnie najbardziej dynamicznie rozwijających się. Aktualnie należy do kluczowych sektorów decydujących o przyszłym wzroście gospodarczym (Informacja, 2017).

Jednym $z$ istotnych czynników stanowiących impuls do wzrostu gospodarczego jest działalność innowacyjna. Działalność badawczo-rozwojowa sektora 
ICT wymaga współpracy wielu podmiotów. Kooperacja przedsiębiorstw często przyjmuje układ klastra (Wojnicka, 2001). Korzyści, jakie płyną z tej formy współpracy, zwiększają efektywność przedsiębiorstw, w rezultacie przekładają się na rozwój całego sektora ICT. Pojęcie klastra pochodzi z angielskiego cluster i oznacza grono lub kiść (Roman, 2013). Prekursorem definicji klastra jest Porter (2001), który podaje, że: „klaster to znajdująca się w geograficznym sąsiedztwie grupa przedsiębiorstw i powiązanych z nimi instytucji zajmujących się określoną dziedziną, połączona podobieństwami i wzajemnie się uzupełniająca”. Wojnacka (2001) dodaje, że działalność klastra wykracza poza kooperacje firm w ramach jednej branży, dotyczy instytucji i przedsiębiorstw z różnych przemysłów, dlatego też mówi się, że skupiska podmiotów są multisektoralne. Kłosiewicz-Górecka (2012) wyodrębniła wspólne elementy istniejących definicji klastra. Są to następujące wyznaczniki: geograficzne skupienie uczestników klastra, powiązania i interakcje pomiędzy przedsiębiorstwami tworzącymi klaster, konkurencja między uczestnikami klastra, współpraca przedsiębiorstw, włączenie do kooperacji podmiotów otoczenia biznesowego oraz nakierowanie ich na wspólny cel przyczyniający się do przepływu wiedzy, technologii oraz innowacji. Wiśniewska i Liczmańska (2014), w oparciu o definicje klastra, wymieniły natomiast następujące czynniki sukcesu przedsiębiorstw, które do niego należą: bliskość geograficzną, kooperację oraz konkurencję. Analizując działanie klastrów, można dokonać ich podziału ze względu na typ (Siłka, 2012). Ogólną ich typologię ze względu na różne kryteria przedstawiono w tabeli 1.

Tabela 1. Typologia klastrów według wybranych kryteriów

\begin{tabular}{|l|l|}
\hline \multicolumn{1}{|c|}{ Kryterium } & \multicolumn{1}{c|}{ Typ klastra } \\
\hline Stadium rozwoju & $\begin{array}{l}\text { Klasyfikacja porównywalna jest do teorii cyklu życia } \\
\text { produktów. Wyróżnia się 4 fazy rozwoju: klastry embrio- } \\
\text { nalne, wzrostowe, dojrzałe oraz schyłkowe }\end{array}$ \\
\hline Zdolność do kreowania miejsc pracy & $\begin{array}{l}\text { Wyróżnia się klastry o stabilnej, rosnącej lub malejącej } \\
\text { zdolności do kreacji miejsc pracy }\end{array}$ \\
\hline $\begin{array}{l}\text { Liczba horyzontalnie powiązanych } \\
\text { sektorów }\end{array}$ & Grono wąskie lub szerokie \\
\hline Zasięg terytorialny klastra & Klastry: lokalne, regionalne, krajowe i ponadnarodowe \\
\hline Pozycja konkurencyjna & $\begin{array}{l}\text { Grono charakteryzujące się słabą lub przeciętną pozycją } \\
\text { konkurencyjną oraz te, które stanowią liderów na pozio- } \\
\text { mie krajowym, światowym }\end{array}$ \\
\hline Liczba stadiów łańcucha produkcyjnego & Podział na klastry głębokie oraz płytkie \\
\hline Znaczenie technologiczne & $\begin{array}{l}\text { Wyróżnia się klastry: niskich, średnich oraz wysokich } \\
\text { technologii }\end{array}$ \\
\hline
\end{tabular}

Źródło: Brodzicki, Szultka (2002). 
Istotnego z punktu przeprowadzonych badań podziału klastrów dokonała Kłosiewicz-Górecka (2012). Wyróżniła cztery grona ze względu na rodzaj działalności, a mianowicie: rolniczo-żywnościowe, przemysłowe, usługowe oraz wysokich technologii.

Tworzenie nowych klastrów jest związane z czerpaniem korzyści wynikających $\mathrm{z}$ członkostwa w nim. Jeżeli współpraca w ramach klastra przebiega poprawnie, to skutkuje poprawą konkurencyjności oraz innowacyjności podmiotów kooperujących. Warto zatem przeanalizować, jakie zyski wiążą się ze współpracą przedsiębiorstw i rozważyć je na poziomie mezoekonomicznym, tak jak w przypadku sektora (ICT). Odnosząc się do wymiaru regionalnego, można stwierdzić, że liczne zjawiska wywierają pozytywny wpływ na konkurencyjność i innowacyjność lokalnej gospodarki, gdyż następuje specjalizacja regionu w danej branży (Weresa, 2017). Funkcjonowanie klastrów w danym regionie świadczy także o jego atrakcyjności i wpływa w dużej mierze na wybór lokalizacji inwestycji zagranicznych (Saniuk i in., 2012). Uznanie klastrów za stymulatory rozwoju gospodarczego przyczyniło się do wykreowania $\mathrm{w}$ wielu państwach polityki klastrowej, w której strukturom klastrowym udzielane jest wsparcie finansowe. Rezultatem tego wsparcia jest ich efektywny rozwój (Drelich-Skulska i in., 2014).

Wielu badaczy przeanalizowało istotną rolę, jaką ICT odgrywa w systemie międzynarodowej konkurencyjność firmy (Abereijo i in., 2009; Flor i Oltra, 2005; Jones i Crack, 2001; López i Garcia, 2005; Powell i Dent-Micallef, 1997; Zeng i in., 2008). Bronzini i Pisalli (2009) oraz Forman i Zeebroeck (2012) dodają, że modele teoretyczne i empiryczne wykazują, iż badania i rozwój oraz technologie informacyjno-komunikacyjne są determinantami wzrostu gospodarczego. Nair (2020) podkreśla znaczący wpływ ICT na wzrost gospodarczy, który zaowocował krajowymi i sektorowymi korporacjami na całym świecie zwiększającymi inwestycje w B+R w gospodarce cyfrowej.

Klastry sektora ICT wnoszą nowe zasoby wiedzy oraz innowacji w gospodarce, mające charakter technologiczny, społeczny i ekologiczny. Spośród funkcji klastrów ICT należy wymienić stymulację sieciowania partnerów klastrowych, jak i przeobrażanie przedsiębiorstw produkcyjnych w inteligentne fabryki. Istotny jest również ich wpływ na zrównoważony rozwój gospodarki opartej na wiedzy (Bembenek, 2017). Założenia zrównoważonego rozwoju dotyczą nieustannego doskonalenia człowieka, gospodarki i ochrony środowiska (Wiktorowski, 2011). Michałowski (2012) zaznacza, że w literaturze przedmiotu zrównoważony rozwój zmienia sposób postrzegania gospodarki opartej na wiedzy, gdyż uwzględnia korzyści płynące z kompleksowych usług środowiska w wymiarze biologiczno-ekologicznym oraz społeczno-gospodarczym. Górka i Łuszczyk (2014) oraz 
Powichrowska (2013) wymieniają natomiast podstawowe wyznaczniki zrównoważonej gospodarki opartej na wiedzy, wśród których znalazły się m.in.:

- rozwój kapitału intelektualnego,

- myślenie i zarządzanie strategiczne,

- postrzeganie wiedzy jako wartości ekonomicznej,

- sprawne wykorzystanie wiedzy i technologii informacyjno-komunikacyjnych,

- tworzenie organizacji uczących się i inteligentnych,

- rozwój przemysłu zaawansowanej technologii,

- zapewnienie wzrostu dobrobytu i jakości życia poprzez wdrażanie innowacji społecznych.

Skórska (2016) twierdzi, że o przyszłości zrównoważonej gospodarki w znacznym stopniu decydują organizacje sieciowe, uczące się, inteligentne, które kształtują i rozwijają twórcze zachowania w swoim środowisku przedsiębiorczym. Wraz ze zrównoważonym rozwojem gospodarki rośnie zapotrzebowanie na wiedzę usług wiedzochłonnych, jak i wyroby projektowane w sektorze zaawansowanej technologii. Jest to wynik wzmacniania innowacji i konkurencyjności współczesnych gospodarek krajowych na całym świecie.

\section{Metodyka badań}

Podmiotem badań, przedstawianych w tych rozważaniach, był sektor ICT, który jest połączeniem przedsiębiorstw produkcyjnych oraz usługowych. W artykule zastosowano klasyfikację stosowaną w statystyce Unii Europejskiej (UE). Według niej do grupy produkcji ICT zaliczono: produkcje sprzętu komputerowego, do przesyłania danych, sieciowego, komunikacyjnego oraz biurowego. Do usług przypisano natomiast: usługi telekomunikacyjne, tworzenie oprogramowania oraz usługi IT. Przedmiotem badań były struktury klastrowe sektora ICT. W celu ich identyfikacji posłużono się wskaźnikiem lokalizacji (LQ), wskaźnikiem specjalizacji (SI) oraz indeksem klastra (CI). Wskaźnik lokalizacji (LQ) wyrażono wzorem:

gdzie:

$$
L Q=\frac{\frac{e_{i}}{e}}{\frac{E_{i}}{E}}
$$

$e_{i}$ - liczba przedsiębiorstw występujących w i-tym sektorze w danym kraju, $e$ - ogólna liczba przedsiębiorstw w danym kraju,

$E_{i}$ - liczba przedsiębiorstw występujących w i-tym sektorze w UE,

$E$ - ogólna liczba przedsiębiorstw w UE. 
Wskaźnik lokalizacji (wskaźnik koncentracji Florence’a) umożliwia ocenę stopnia koncentracji przestrzennej przedsiębiorstw z konkretnego działu gospodarki bądź sektora w stosunku do przeciętnej koncentracji w UE (Nazarczuk, 2013). Wskaźnik specjalizacji odnosi się natomiast do poziomu aktywności zawodowej ludności w określonym sektorze w stosunku do przeciętnej aktywności w UE. Umożliwia to identyfikację względnej specjalizacji w wytwarzaniu dóbr danego sektora. Wskaźnik specjalizacji (SI) obliczono zgodnie ze wzorem (Karmowska, 2011):

$$
S I=\frac{\frac{Z_{i}}{Z}}{\frac{Z_{i}}{Z}}
$$

gdzie:

$z_{i}$ - liczba pracujących w sektorze wysokiej techniki w danym kraju, $z$ - ogólna liczba pracujących w danym kraju,

$Z_{i}$ - liczba pracujących w sektorze wysokiej techniki w UE, $Z$ - ogólna liczba pracujących w UE.

Sternberg i Litzenberger (2004) odnieśli się w indeksie klastra (CI) do wskaźnika specjalizacji (SI). Indeks klastra dla sektora klastra $k \mathrm{w}$ regionie $i$ zdefiniowano jako iloczyn względnej koncentracji przemysłu (ID), gęstości zatrudnienia $\mathrm{w}$ danym sektorze (SI) oraz odwrotności względnej wielkości przedsiębiorstw (BG) i wyrażono następującym wzorem (Główka, 2017):

$$
C I_{i}^{k}=I D_{i}^{k} * I B_{i}^{k} * \frac{1}{B G_{i}^{k}}
$$

Uwzględnione w obliczeniach składowe obliczono zgodnie ze wzorami (Główka, 2017):

$$
I D_{l}^{k}=\frac{\frac{e_{i}^{k}}{a_{i}}}{\frac{\sum_{l} e_{l}^{k}}{\sum_{l} a_{l}}}, I B_{i}^{k}=S I=\frac{\frac{e_{i}^{k}}{\sum_{j} e_{i}^{j}}}{\frac{\sum_{l} e_{l}^{k}}{\sum_{l} \sum_{j} e_{l}^{j}}}, B G_{i}^{k}=\frac{\frac{e_{i}^{k}}{b_{i}^{k}}}{\frac{\sum_{l} e_{l}^{k}}{\sum_{l} b_{l}^{k}}}
$$

gdzie:

$a_{i}$ - powierzchnia regionu $i$,

$\sum_{l} a_{l}$ - łączna powierzchnia wszystkich regionów, 
$b_{i}^{k}$ - liczba podmiotów w sektorze $k \mathrm{w}$ regionie $i$,

$\sum_{l} b_{l}^{k}$ - łączna liczba podmiotów w sektorze $k$ we wszystkich regionach,

$e_{i}^{k}$ - liczba zatrudnionych w sektorze $k \mathrm{w}$ regionie $i$,

$\sum_{l} e_{l}^{k}-$ lączna liczba zatrudnionych w sektorze $k$ we wszystkich regionach,

$\sum_{j} e_{i}^{j}$ - łączna liczba zatrudnionych w regionie $i$ we wszystkich sektorach,

$\sum_{l} \sum_{j} e_{l}^{j}$ - łączna liczba zatrudnionych.

Analiza obejmowała okres 3 lat (najnowsze dostępne dane w bazie Eurostat, stan na 26.02.2021 r.), a mianowicie lata 2016-2018 (w przypadku braku danych wykorzystano najnowsze dane).

Badaniami objęto państwa wchodzące w skład członkowski UE. Dane pozyskano z bazy Eurostat.

\section{Wyniki badań i dyskusja}

W związku z postępującą globalizacją następuje przesuwanie obszarów klastrów poza granice państwa. Jednym $z$ istotniejszych kryteriów uwzględnianych przy określaniu koncentracji przestrzennej jest identyfikacja liczby miejsc pracy na wybranym terenie. Badania te przeprowadzono, stosując jeden z najczęściej przyjmowanych mierników do identyfikacji skupień - wskaźnik lokalizacji. W tabeli 2 zaprezentowano poziom wskaźnika LQ obliczony na podstawie liczby przedsiębiorstw (z podziałem na produkcyjne i usługowe).

Z przeprowadzonych badań wynika, że w latach 2016-2018 w dziesięciu państwach należących do Unii Europejskiej wskaźnik LQ był na ponadprzeciętnym poziomie $(>1,25)$. W grupie tej znalazły się następujące państwa: Luksemburg, Niderlandy, Szwecja, Dania, Estonia, Węgry, Łotwa, Polska, Słowenia i Austria. Poziom wskaźnika LQ przekraczający 1,25 świadczy o występowaniu skupisk przedsiębiorstw sektora ICT we wspomnianych państwach. Na tej podstawie można stwierdzić istnienie potencjalnych klastrów. Pozostałe państwa, w których wskaźnik LQ wynosił powyżej 1, to: Rumunia, Belgia, Niemcy, Irlandia, Chorwacja, Czechy i Słowacja. Poziom ten świadczy o wytwarzaniu nadwyżki oferowanych dóbr sektora ICT w wymienionych państwach. Z badań przeprowadzonych przez Maticiuc (2020) wynika, że w Rumuni działa 11 klastrów utworzonych w: Bukareszcie, Cluj Napoca, Timișoara, Iași, Braşov, Miercurea Ciuc oraz Craiova. Nadwyżka powstała we wspomnianych państwach była eksportowana na rynki zagraniczne. Efektem tych działań była wysoka konkurencyjność wymienionych państw sektora ICT. Wskaźnik lokalizacji poniżej 1 
odnotowano na Malcie, w: Finlandii, Francji, Bułgarii, Litwie, Cyprze, Włoszech, Hiszpanii, Grecji i Portugalii. Państwa te w celu zaspokajania popytu na dobra ICT importowały je z zagranicy, w związku z czym były obciążone dodatkowymi kosztami wynikającymi z zawartych transakcji.

Tabela 2. Wskaźnik lokalizacji (LQ) sektora ICT w krajach Unii Europejskiej

\begin{tabular}{|c|c|c|c|c|c|c|c|}
\hline \multirow[b]{2}{*}{ Państwo } & \multicolumn{3}{|c|}{ Produkcja ICT } & \multicolumn{3}{|c|}{ Usługi ICT } & \multirow{2}{*}{$\begin{array}{c}\text { Sektor ICT } \\
\text { Średnia } \\
2016-2018\end{array}$} \\
\hline & 2016 & 2017 & 2018 & 2016 & 2017 & 2018 & \\
\hline Luksemburg & 0,10 & 0,09 & 0,09 & 1,85 & 1,77 & 1,80 & 1,76 \\
\hline Niderlandy & 0,83 & 0,84 & 0,84 & 1,82 & 1,73 & 1,70 & 1,73 \\
\hline Szwecja & 1,53 & 1,44 & 1,28 & 1,75 & 1,67 & 1,73 & 1,71 \\
\hline Dania & 1,30 & 1,34 & 1,26 & 1,71 & 1,67 & 1,67 & 1,68 \\
\hline Estonia & 1,00 & 0,95 & 0,87 & 1,52 & 1,56 & 1,65 & 1,56 \\
\hline Węgry & 1,50 & 1,43 & 1,36 & 1,52 & 1,48 & 1,51 & 1,50 \\
\hline Łotwa & 1,02 & 1,08 & 1,01 & 1,47 & 1,43 & 1,49 & 1,45 \\
\hline Polska & 1,17 & 1,21 & 1,25 & 1,38 & 1,45 & 1,44 & 1,42 \\
\hline Słowenia & 1,73 & 1,68 & 1,63 & 1,41 & 1,39 & 1,41 & 1,41 \\
\hline Austria & 0,85 & 0,88 & 0,88 & 1,27 & 1,24 & 1,28 & 1,26 \\
\hline Rumunia & 1,15 & 1,08 & 1,03 & 1,21 & 1,19 & 1,20 & 1,19 \\
\hline Belgia & 0,45 & 0,47 & 0,33 & 1,19 & 1,18 & 1,23 & 1,18 \\
\hline Niemcy & 1,56 & 1,52 & 1,66 & 1,10 & 1,11 & 1,04 & 1,10 \\
\hline Irlandia & 0,94 & 0,94 & 0,93 & 1,16 & 1,06 & 1,07 & 1,09 \\
\hline Chorwacja & 2,57 & 2,56 & 2,45 & 1,03 & 1,02 & 1,05 & 1,07 \\
\hline Czechy & 2,38 & 2,36 & 2,17 & 0,92 & 0,98 & 1,02 & 1,00 \\
\hline Słowacja & 2,15 & 2,16 & 2,84 & 0,95 & 0,95 & 0,99 & 1,00 \\
\hline Malta & 0,61 & 0,44 & 0,32 & 0,99 & 1,06 & 0,97 & 0,99 \\
\hline Finlandia & 1,38 & 1,39 & 1,29 & 0,95 & 0,93 & 0,93 & 0,95 \\
\hline Francja & 0,56 & 0,52 & 0,50 & 0,95 & 0,97 & 0,95 & 0,94 \\
\hline Bułgaria & 0,68 & 0,73 & 0,70 & 0,86 & 0,86 & 0,88 & 0,86 \\
\hline Litwa & 0,32 & 0,36 & 0,32 & 0,83 & 0,79 & 0,82 & 0,80 \\
\hline Cypr & - & - & - & 0,72 & 0,77 & 0,86 & 0,76 \\
\hline Włochy & 0,93 & 0,92 & 0,88 & 0,71 & 0,68 & 0,68 & 0,69 \\
\hline Hiszpania & 0,55 & 0,57 & 0,55 & 0,63 & 0,64 & 0,62 & 0,63 \\
\hline Grecja & 0,44 & 0,45 & 0,44 & 0,47 & 0,45 & 0,45 & 0,46 \\
\hline Portugalia & 0,29 & 0,29 & 0,25 & 0,44 & 0,44 & 0,45 & 0,44 \\
\hline
\end{tabular}

Źródło: opracowanie własne na podstawie sbs_na_sca_r2 (Eurostat).

W celu przeprowadzenia wnikliwej analizy sektora rozbito go na przedsiębiorstwa produkcyjne i usługowe. Istotnym elementem obserwacji jest Luksemburg. Charakteryzował się najwyższym wskaźnikiem LQ $(1,76)$ wynikającym z liczby przedsiębiorstw usługowych działających na terenie tego państwa. Przedsiębiorstwa produkcyjne w tym kraju praktycznie nie występowały. Niderlandy, 
Austria, Belgia i Irlandia to państwa, które eksportowały nadwyżkę oferowanych przez przedsiębiorstwa usług. Importowały natomiast produkty ICT. Chorwacja, Czechy oraz Słowacja wyróżniały się w badanym okresie znaczącymi skupiskami przedsiębiorstw produkcyjnych (LQ powyżej 2). W Finlandii również odnotowano ponadprzeciętny poziom wskaźnika LQ $(1,38)$ w odniesieniu do produkcji ICT, która świadczy o istotnym znaczeniu tego sektora w tym państwie. Zgodnie z badaniami Maryska i in. (2012) największy udział sektora ICT w PKB w UE występuje w Finlandii (8\%) za sprawą przemysłu ICT. W Chorwacji, Czechach i Finlandii działała natomiast niska liczba przedsiębiorstw usługowych. W okresie badawczym liczba przedsiębiorstw we wszystkich państwach była stabilna. W badaniu nie uwzględniono przedsiębiorstw produkcyjnych z Cypru ze względu na brak dostępnych danych.

Kolejnym miernikiem stosowanym do identyfikacji struktur klastrowych jest wskaźnik specjalizacji (SI). Vu (2011) podkreśla, że kapitał ludzki jest bardziej efektywny dzięki wykorzystaniu ICT, ponieważ poprawia dostęp do informacji, uczenia się i komunikacji. Podobnego zdania są Skorupińska i Torrent-Sellens (2017), którzy podkreślają, że przedsiębiorstwa sektora ICT nie przynoszą pozycji konkurencyjnej dopóki pracownicy nie rozwiną niezbędnych umiejętności technologicznych. W tabeli 3 przedstawiono dane obliczone na podstawie liczby zatrudnionych $\mathrm{w}$ przedsiębiorstwach produkcyjnych oraz usługowych sektora ICT.

Przyjmując wielkość zatrudnienia jako jedno z głównych kryteriów identyfikacji klastrów, największy potencjał klastrowy sektora ICT występował w badanym okresie w następujących państwach: Szwecji, Malcie, Luksemburgu, Finlandii, Estonii, na Węgrzech i w Danii. Wskaźnik specjalizacji w tych krajach kształtował się na poziomie 1,28-1,59. Świadczy to o występowaniu skupisk zatrudnionych specjalistów ICT na wymienionych terenach. Wartości wskaźnika SI $>1$ odnotowano we: Francji, na Łotwie, w Rumunii, Bułgarii, Słowenii, Niderlandach oraz Belgii. W pozostałych państwach członkowskich wskaźnik SI nie przekraczał 1, jego wartość wyniosła 0,60-0,98.

Tabela 3. Wskaźnik specjalizacji (SI) sektora ICT w krajach Unii Europejskiej

\begin{tabular}{|l|c|c|c|c|c|c|c|}
\hline \multirow{2}{*}{\multicolumn{1}{c|}{ Państwo }} & \multicolumn{3}{c|}{ Produkcja ICT } & \multicolumn{3}{c|}{ Usługi ICT } & Sektor ICT \\
\cline { 2 - 8 } & $\mathbf{2 0 1 6}$ & $\mathbf{2 0 1 7}$ & $\mathbf{2 0 1 8}$ & $\mathbf{2 0 1 6}$ & $\mathbf{2 0 1 7}$ & $\mathbf{2 0 1 8}$ & $\begin{array}{c}\text { Średnia } \\
\mathbf{2 0 1 6 - 2 0 1 8}\end{array}$ \\
\hline Szwecja & 0,74 & 0,73 & 0,67 & 1,70 & 1,68 & 1,66 & 1,59 \\
\hline Malta & - & - & - & - & - & - & 1,57 \\
\hline Luksemburg & - & - & - & 1,65 & 1,67 & 1,65 & 1,50 \\
\hline Finlandia & 1,96 & 1,96 & 1,84 & 1,37 & 1,39 & 1,40 & 1,43 \\
\hline Estonia & 2,81 & 2,92 & 2,78 & 1,10 & 1,20 & 1,26 & 1,33 \\
\hline
\end{tabular}




\begin{tabular}{|l|c|c|c|c|c|c|c|}
\hline Węgry & 3,84 & 4,01 & 3,58 & 1,08 & 1,08 & 1,07 & 1,32 \\
\hline Dania & 0,64 & 0,64 & 0,58 & 1,37 & 1,35 & 1,33 & 1,28 \\
\hline Francja & 1,04 & 0,96 & 1,30 & 1,22 & 1,25 & 1,19 & 1,20 \\
\hline Łotwa & 0,53 & 0,60 & 0,58 & 1,21 & 1,25 & 1,31 & 1,19 \\
\hline Rumunia & 1,38 & 1,53 & 1,50 & 1,07 & 1,10 & 1,14 & 1,13 \\
\hline Bułgaria & 0,68 & 0,72 & 0,70 & 1,08 & 1,11 & 1,13 & 1,07 \\
\hline Słowacja & 1,95 & 1,94 & 1,85 & 0,97 & 0,96 & 0,98 & 1,06 \\
\hline Niderlandy & 0,43 & 0,40 & 0,41 & 1,18 & 1,09 & 1,05 & 1,04 \\
\hline Belgia & 0,56 & 0,56 & 0,52 & 1,05 & 1,04 & 1,07 & 1,01 \\
\hline Czechy & 1,67 & 1,70 & 1,51 & 0,90 & 0,92 & 0,93 & 0,98 \\
\hline Niemcy & 1,12 & 1,11 & 1,12 & 0,92 & 0,92 & 0,99 & 0,96 \\
\hline Polska & 1,12 & 1,21 & 1,10 & 0,92 & 0,95 & 0,91 & 0,95 \\
\hline Słowenia & 1,27 & 1,24 & 1,23 & 0,93 & 0,91 & 0,90 & 0,94 \\
\hline Włochy & 0,93 & 0,91 & 0,86 & 0,95 & 0,93 & 0,90 & 0,92 \\
\hline Cypr & - & - & - & 0,99 & 0,97 & 1,02 & 0,90 \\
\hline Austria & 1,11 & 1,13 & 1,11 & 0,89 & 0,88 & 0,86 & 0,90 \\
\hline Chorwacja & 1,01 & 1,00 & 0,97 & 0,84 & 0,86 & 0,89 & 0,88 \\
\hline Hiszpania & 0,35 & 0,34 & 0,31 & 0,93 & 0,92 & 0,91 & 0,87 \\
\hline Litwa & 0,43 & 0,51 & 0,43 & 0,85 & 0,84 & 0,85 & 0,81 \\
\hline Portugalia & 0,71 & 0,69 & 0,62 & 0,70 & 0,71 & 0,73 & 0,71 \\
\hline Grecja & 0,18 & 0,13 & 0,12 & 0,66 & 0,66 & 0,62 & 0,60 \\
\hline Irlandia & brak danych & & & & \\
\hline Zro: ora & & & & & \\
\hline
\end{tabular}

Źródło: opracowanie własne na podstawie sbs_na_sca_r2 (Eurostat).

Zatrudnienie w sektorze ICT zarówno w dziale produkcyjnym, jak i usługowym w całej UE kształtuje się na podobnym poziomie. Skupiając natomiast uwagę na poszczególnych państwach, można podzielić je na dwie grupy. Do pierwszej z nich można zaliczyć przedsiębiorstwa zatrudniające więcej pracowników produkcyjnych. Drugą grupę stanowią kraje, w których pracuje więcej pracowników usługowych. Państwami o przewadze zatrudnionych w przemyśle produkcyjnym były: Słowacja, Czechy, Niemcy, Polska, Słowenia, Austria oraz Chorwacja. Wśród państw o przewadze zatrudnionych w przedsiębiorstwach usługowych znalazły się: Dania, Łotwa, Bułgaria, Niderlandy oraz Belgia. Czechy należą do grupy państw, których wskaźnik SI sektora ICT nie przekroczył w badanym okresie 1. Świadczy to o braku lub niewielkim stopniu występowania skupisk specjalistów. Tezę tę potwierdzają badania Maryska i in. (2012) dotyczące znaczenia sektora i edukacji uniwersyteckiej ICT w rozwoju czeskiej gospodarki, z których wynika luka specjalistów na studiach wyższych w zakresie technologii informacyjno-komunikacyjnych. Szczególną uwagę należy zwrócić na Estonię i Węgry. W tych państwach występują skupiska specjalistów ICT w obu działach, natomiast znacznie wyższe w przemyśle produkcyjnym - odpowiednio 2,78 i 3,58. W pozostałych państwach zatrudnienie w obydwu działach kształtowało 
się równomiernie. Ze względu na brak szczegółowych danych analiza Malty, Luksemburga i Cypru była utrudniona. Irlandia ze względu na całkowity brak danych została zatem pominięta w badaniach wskaźnika SI.

Ostatnim miernikiem, wykorzystanym do rozpoznania potencjalnych skupisk przedsiębiorstw, był indeks klastra (CI). Wskaźnik ten nawiązuje do wskaźnika SI, natomiast wymaga większej liczby danych, a obliczenia są bardziej rozbudowane. Rezultatem tych wyliczeń jest dokładne określenie przestrzennej demarkacji struktur klastrowych. W tabeli 4 zaprezentowano wielkości CI w oparciu o względną koncentrację przemysłu, względną gęstość zatrudnienia oraz względną wielkość przedsiębiorstw. W latach 2016-2018 najwyższym potencjałem klastrowym sektora ICT charakteryzowała się Malta $(27,91)$. Istotnym czynnikiem wpływającym na to była względna koncentracja przemysłu (ID). Należy zaznaczyć, że Malta to najmniejsze powierzchniowo analizowane państwo $\left(316 \mathrm{~km}^{2}\right)$, stąd duża koncentracja zatrudnionych. Za państwa o wysokim potencjale klastrowym uznano: Niderlandy, Luksemburg, Belgię, Czechy, Węgry, Danię. Równie wysoki indeks CI (CI>1,25) zaobserwowano w: Słowacji, Słowenii, Włoszech, Polsce i Niemczech. W pozostałych państwach $\mathrm{CI}<1$, co świadczy o niskim rozwoju sektora ICT. Nie odgrywa on kluczowej roli w kształtowaniu gospodarki tych państw oraz nie zaspakaja potrzeb konsumentów, przez co powstaje konieczność importu produktów i usług z zagranicy.

Tabela 4. Indeks klastra (CI) sektora ICT w krajach Unii Europejskiej

\begin{tabular}{|l|c|c|c|c|c|c|c|}
\hline \multirow{2}{*}{ Państwo } & \multicolumn{3}{c|}{ Produkcja ICT } & \multicolumn{3}{c|}{ Usługi ICT } & Sektor ICT \\
\cline { 2 - 8 } & $\mathbf{2 0 1 6}$ & $\mathbf{2 0 1 7}$ & $\mathbf{2 0 1 8}$ & $\mathbf{2 0 1 6}$ & $\mathbf{2 0 1 7}$ & $\mathbf{2 0 1 8}$ & Średnia \\
\hline Niderlandy & 1,88 & 1,83 & 1,92 & 11,41 & 10,21 & 10,05 & 9,67 \\
\hline Luksemburg & - & - & - & 7,36 & 7,49 & 7,54 & 6,52 \\
\hline Belgia & 0,99 & 1,05 & 0,68 & 4,86 & 4,96 & 5,22 & 4,64 \\
\hline Czechy & 9,96 & 10,08 & 8,25 & 2,07 & 2,26 & 2,39 & 2,43 \\
\hline Węgry & 6,60 & 6,82 & 5,98 & 1,88 & 1,90 & 1,98 & 2,33 \\
\hline Dania & 0,82 & 0,87 & 0,73 & 2,31 & 2,27 & 2,22 & 2,11 \\
\hline Słowacja & 7,39 & 7,84 & 10,03 & 1,61 & 1,71 & 1,87 & 1,92 \\
\hline Słowenia & 2,91 & 2,83 & 2,74 & 1,74 & 1,72 & 1,73 & 1,77 \\
\hline Włochy & 2,06 & 2,00 & 1,76 & 1,61 & 1,50 & 1,43 & 1,49 \\
\hline Polska & 1,37 & 1,59 & 1,65 & 1,33 & 1,50 & 1,58 & 1,47 \\
\hline Niemcy & 2,33 & 2,31 & 2,58 & 1,36 & 1,40 & 1,43 & 1,42 \\
\hline Francja & 0,51 & 0,40 & 0,53 & 1,01 & 0,97 & 0,91 & 0,93 \\
\hline Austria & 0,70 & 0,77 & 0,70 & 0,85 & 0,85 & 0,80 & 0,83 \\
\hline Szwecja & 0,34 & 0,32 & 0,23 & 0,90 & 0,87 & 0,78 & 0,78 \\
\hline Cypr & - & - & - & 0,75 & 0,83 & 1,00 & 0,74 \\
\hline Estonia & 0,85 & 0,91 & 0,79 & 0,51 & 0,61 & 0,68 & 0,65 \\
\hline
\end{tabular}




\begin{tabular}{|l|c|c|c|c|c|c|c|}
\hline Łotwa & 0,19 & 0,22 & 0,20 & 0,62 & 0,61 & 0,65 & 0,58 \\
\hline Portugalia & 0,36 & 0,36 & 0,29 & 0,55 & 0,56 & 0,60 & 0,55 \\
\hline Hiszpania & 0,20 & 0,20 & 0,17 & 0,61 & 0,61 & 0,56 & 0,55 \\
\hline Bułgaria & 0,27 & 0,31 & 0,29 & 0,54 & 0,57 & 0,59 & 0,54 \\
\hline Rumunia & 0,60 & 0,66 & 0,62 & 0,49 & 0,52 & 0,55 & 0,52 \\
\hline Chorwacja & 1,31 & 1,31 & 1,23 & 0,44 & 0,45 & 0,48 & 0,47 \\
\hline Litwa & 0,08 & 0,11 & 0,09 & 0,40 & 0,40 & 0,43 & 0,38 \\
\hline Grecja & 0,09 & 0,06 & 0,06 & 0,36 & 0,31 & 0,29 & 0,29 \\
\hline Finlandia & 0,35 & 0,36 & 0,31 & 0,17 & 0,17 & 0,17 & 0,18 \\
\hline Irlandia & \multicolumn{7}{|l|}{ brak danych } \\
\hline
\end{tabular}

Źródło: opracowanie własne na podstawie sbs_na_sca_r2 (Eurostat).

W większości państw należących do UE indeks CI jest na zbliżonym poziomie w dziale produkcyjnym i usługowym. Znacząco wyższym indeksem CI działalności produkcyjnych odznaczają się: Czechy, Węgry, Słowacja Słowenia, Niemcy i Chorwacja. Słowacja osiągnęła jeden z najwyższych indeksów CI sektora w obszarze produkcji $(10,03)$ - występują w niej zarówno skupiska przedsiębiorstw, jak i specjalistów ICT. Madudova i in. (2018) znaleźli związki pomiędzy koncentracją geograficzną, specjalizacją regionalną, płacami i zatrudnieniem, uznając sektor ICT na Słowacji za zrównoważony pod względem równowagi ekonomicznej. Z kolei wyższy indeks CI przedsiębiorstw usługowych stwierdzono w Niderlandach, Belgii oraz Danii. Ze względu na brak danych nie można stwierdzić przewagi (lub jej braku)w działach sektora ICT w państwach, takich jak: Malta, Luksemburg, Cypr i Irlandia.

Z przeprowadzonych badań wynika, że znaczenie sektora ICT w poszczególnych krajach UE zależy od liczby przedsiębiorstw informacyjno-komunikacyjnych oraz liczby specjalistów zatrudnionych w sektorze. Maryska i in. (2012) twierdzą, że wszystkie kraje rozwinięte są zależne od ICT. Z badań, które przeprowadzili, wynika, że wpływ na to mają inwestycje w sektor ICT oraz liczba zatrudnionych specjalistów. Vu (2011), Ho i in. (2011) oraz Warr i Ayres (2012) podkreślają związek między PKB a ICT. Pozytywny wpływ ICT na PKB zauważyli Fernandez-Portillo i in. (2020) oraz Vu i in. (2020). Dodatkowo Savulescu (2015) w badaniach zaobserwowała, że kraje rozwinięte wprowadzają innowacje w celu zwiększenia swojej konkurencyjności, podczas gdy państwa rozwijające się czynią wysiłki w celu zwiększenia wykorzystania ICT, aby pobudzić wzrost gospodarczy. Pomimo głównego nurtu sugerującego pozytywny wpływ ICT na wzrost gospodarczy (Vu i in. 2020) istnieją również takie, które kwestionują zależność między ICT a wzrostem gospodarczym. Badania przeprowadzone przez Thompson i Garbacz (2011) oraz Haller i Lyons (2015) nie wskazują wpływu 
zmiennych ICT na produktywność biznesową. Oznacza to, że wpływ sektora ICT na wynik gospodarczy nie jest jednorodny we wszystkich państwach, różni się w zależności od poziomu ekonomicznego (Albiman, Sulong, 2017; Mayer i in., 2020; Yazdan, Hossein, 2013).

\section{Zakończenie}

Skupiska przedsiębiorstw, ich wielkość oraz liczba specjalistów w istotny sposób wpływają na znaczenie sektora ICT w państwach UE. Krajami o wysokim poziomie wskaźnika LQ uznano: Luksemburg, Niderlandy, Szwecję, Danię, Estonię, Węgry, Łotwę, Polskę, Słowenię i Austrię. W większości wymienionych państw przeważały przedsiębiorstwa usługowe. Wskaźnik SI o najwyższym poziomie odnotowano w: Szwecji, Malcie, Luksemburgu, Finlandii, Estonii, Węgrzech i Danii. Gęstość zatrudnienia w produkcji i usługach była zróżnicowana w poszczególnych państwach. Na podstawie koncentracji przedsiębiorstw, gęstości zatrudnienia oraz wielkości przedsiębiorstw za państwo o najwyższym potencjale klastrowym uznano Maltę. Wysoki potencjał odnotowano w Niderlandach, Luksemburgu, Belgii, Czechach, Węgrzech oraz Danii. W artykule w sektorze ICT uwzględniono zarówno przedsiębiorstwa produkcyjne ICT, jak i przedsiębiorstwa usługowe ICT. Miało to wpływ na uzyskane wyniki badań i wynikające z nich wnioski. W kontekście znaczenia sektora ICT oraz jego wpływu na rozwój gospodarczy zasadne jest poszerzenie dotychczasowych badań z wykorzystaniem innych wskaźników.

\section{Bibliografia}

Abereijo, I.O., Adegbite, S.A., Ilori, M.O, Adeniyi, A.A., Aderemi, H.A. (2009). Technological innovation sources and institutional supports for manufacturing small and medium enterprises in Nigeria. Journal of Technology Management and Innovation, 4(2), 82-89.

Albiman, M.M., Sulong, Z. (2017). The linear and non-linear impacts of ICT on economic growth, of disaggregate income groups within SSA region. Telecommun, $41(7-8), 555-572$.

Bembenek, R. (2017). Klastry przemysłu 4.0 w zrównoważonej gospodarce opartej na wiedzy. Prace Naukowe Uniwersytetu Ekonomicznego we Wrocławiu, 491, 31-44. Brodzicki, T., Szultka, S. (2002). Koncepcja klastrów a konkurencyjność przedsiębiorstw. Organizacja i Kierowanie, 4, 45-60. 
Bronzini, R., Piselli, P. (2009). Determinants of long-run regional productivity with geographical spillovers: the role of $R \& D$, human capital and public infrastructure. Regional Science and Urban Economics, 39(2), 187-199.

Drelich-Skulska, B. (2014). Klastry jako nośnik innowacyjności - ujęcie teoretyczne. W: B. Drelich-Skulska, A.M. Jankowiak, S. Mazurek (red.), Klastry jako nośnik innowacyjności przedsiębiorstw i regionów. Czy doświadczenia azjatyckie można wykorzystać w warunkach gospodarki polskiej? (s. 11). Wrocław: Wydawnictwo Uniwersytetu Ekonomicznego we Wrocławiu.

Fernández-Portillo, A., Almodóvar-González, M., Hernández-Mogollón, R. (2020). Impact of ICT development on economic growth. A study of OECD European union countries. Technology in Society, 63, 101420.

Flor, M., Oltra, M.J. (2005). The influence of firms' technological capabilities on export performance in supplier-dominated industries: the case of ceramic tiles firms. R\&D Management, 35(3), 333-347.

Forman, C., Zeebroeck, N.V. (2012). From wires to partners: How the Internet has fostered R\&D collaborations within firms. Management science, 58(8), 1549-1568.

Główka, C. (2017). Znaczenie organizacji klastrowej dla środowiska potrójnej helisy na przykładzie sektora poligrafii i reklamy subregionu leszczyńskiego. Poznań: Uniwersytet Ekonomiczny w Poznaniu.

Górka, K., Łuszczyk, M. (2014). Zielona gospodarka i gospodarka oparta na wiedzy a rozwój trwały. Optimum. Studia Ekonomiczne, 3(69), 22-31.

Haller, S.A., Lyons, S. (2015). Broadband adoption and firm productivity: evidence from Irish manufacturing firms. Telecommunications Policy, 39(1), 1-13.

Ho, S.C., Kauffman, R.J., Liang, T.P. (2011). Internet-based selling technology and ecommerce growth: a hybrid growth theory approach with cross-model inference. Information and Technology Management, 12, 409-429.

Informacja na temat potencjału innowacyjnej gospodarki cyfrowej w Polsce. (2017). Warszawa: Ministerstwo cyfryzacji.

Jones, M., Crack, D. (2001). High-technology firms' perceptions of their international competitiveness. Strategic Change, 10(3), 129-138.

Karmowska, G. (2011). Badanie i pomiar rozwoju regionalnego na przykładzie województwa zachodniopomorskiego. Roczniki Nauk Rolniczych, 98(2), 85-93.

Kłosiewicz-Górecka, U. (2012). Klastry - idea i praktyka w Polsce. Handel Wewnętrzny, 58(1), 3-11.

Lopez, J. Garcia, R. (2005). Technology and export behavior: a resource-based view approach. International Business Review, 14(5), 539-57.

Madudova, E., Čorejova, T., Valica, M. (2018). Economic sustainability in a wider context: Case study of considerable ICT sector sub-divisions. Sustainability, 10(7), 2511. 
Maryska, M., Doucek, P., Kunstova, R. (2012). The Importance of ICT Sector and ICT University Education for Economic Development. Procedia - Social and Behavioral Sciences, 55(5), 1060-1068.

Maticiuc, M.D. (2020). Location as a key factor in cluster development. Focus on the ICT sector in Romania. Analele Universitatii "Eftimie Murgu" Resita: Fascicola II, Studii Economice, 27, 78-85.

Mayer, W., Madden, G., Wu, C. (2020). Broadband and economic growth: a reassessment. Information Technology for Development, 26(1), 128-145.

Michałkowski, A. (2012). Ecosystem services in the light of a sustainable knowledge-based economy. Problemy Ekorozwoju - Problems OfSustainable Development, $7(7), 97-106$.

Nair, M., Pradhan, R.P., Arvin, M.B. (2020). Endogenous dynamics between R\&D, ICT and economic growth: Empirical evidence from the OECD countries. Technology in Society, 62, 101315.

Nazarczuk, J.M. (2013). Potencjał rozwojowy a aktywność inwestycyjna województw i podregionów Polski. Olsztyn: Wydawnictwo Uniwersytetu Warmińsko-Mazurskiego.

Perspektywy rozwoju polskiej branży ICT do roku 2025. (2017). Warszawa: Polska Agencja Rozwoju Przedsiębiorczości.

Porter, M.E. (2001). Porter o konkurencji (tłum. A. Ehrlich). Warszawa: Polskie Wydawnictwo Ekonomiczne.

Powell, T.C., Dent-Micallef, A. (1997). Information technology as competitive advantage: the role of human, business, and technology resources. Strategic Management Journal, 18(5), 375-405.

Powichrowska, B. (red.). (2013). Zrównoważona gospodarka oparta na wiedzy. Wybrane problemy. Białystok: Wyższa Szkoła Ekonomiczna w Białymstoku.

Roman, M. (2013). Klastry jako forma współdziałania w działalności turystycznej. Zarządzanie i Finanse, 1(11), 309-320.

Saniuk, A., Saniuk, S., Jakabova, M. (2012). Korzyści i bariery tworzenia klastrów przemysłowych w Polsce. Ekonomiczne Problemy Usług, 94(719), 277-292.

Siłka, P. (2012). Potencjał innowacyjny wybranych miast Polski a ich rozwój gospodarczy. Warszawa: Instytut Geografii i Przestrzennego Zagospodarowania PAN.

Skórska, A. (2016). Sektor high-tech jako czynnik wzrostu konkurencyjności polskiej gospodarki w perspektywie 2020 roku. Zarzadzanie i Finanse, 14(3), 237-252.

Skorupińska, A., Torrent-Sellens, J. (2017). ICT, innovation and productivity: evidence based on eastern European manufacturing companies. Journal of the Knowledge Economy, 8(2), 768-788. 
Sternberg, R., Litzenberger, T. (2004). Regional Clusters in Germany their Geography and their Relevance for Entrepreneurial Activities. European Planning Studies, 12(6), 767-791.

Thompson, H.G., Garbacz, C. (2011). Economic impacts of mobile versus fixed broadband. Telecommunications Policy, 35(11), 999-1009.

Vu, K., Hanafizadeh, P., Bohlin, E. (2020). ICT as a driver of economic growth: a survey of the literature and directions for future research. Telecommunications Policy, 44(2), 101922.

$\mathrm{Vu}, \mathrm{K} . \mathrm{M}$. (2011). ICT as a source of economic growth in the information age: empirical evidence from the 1996-2005 period. Telecommunications Policy, 35(4), 357-372.

Warr, B., Ayres, R.U. (2012). Useful work and information as drivers of economic growth. Ecological Economy, 73, 93-102.

Weresa, M.A., Kowalski, A.M., Sieńko-Kułakowska, E.B. (2017). Rozwój klastrów i metody ewaluacji. Warszawa: Oficyna Wydawnicza SGH.

Wiktorowski, K. (2011). Zrównoważony rozwój oparty na wiedzy a budowanie tożsamości regionalnej. W: B. Poskrobko (red.), Uwarunkowania rozwoju zrównoważonej gospodarki opartej na wiedzy. Białystok: Wyższa Szkoła Ekonomiczna w Białymstoku.

Wiśniewska, A., Liczmańska, K. (2014). Definicyjne cechy klastrów a kluczowe czynniki sukcesu. W: W. Harasim (red.), Człowiek i organizacja - dylematy współczesnego zarządzania (s. 52-54). Warszawa: Wyższa Szkoła Promocji.

Wojnicka, E. (red.). (2006). Perspektywy rozwoju małych i średnich przedsiębiorstw wysokich technologii w Polsce do 2020 roku. Warszawa: Polska Agencja Rozwoju Przedsiębiorczości.

Yazdan, G.F., Hossein, S.S.M. (2013). FDI and ICT effects on productivity growth. Procedia - Social and Behavioral Sciences, 93, 1710-1715.

Zeng, S.X., Xie, X.M., Tam, C.M., Wan, T.W. (2008). Competitive priorities of manufacturing firms for internationalization: empirical research. Measuring Business Excellence, 12(3), 44-55.

\section{Streszczenie}

Od wielu lat zmiany zachodzące w społeczeństwie i gospodarce mają wyraźnie charakter globalny. Technologie informacyjno-telekomunikacyjne (ICT) przyczyniają się do tych zmian i znajdują odzwierciedlenie w oferowanych produktach oraz usługach. Przedsiębiorstwa sektora ICT szybko dostosowują się do nowych warunków i wymagań społeczeństwa informacyjnego, w którym przetwarzanie informacji z wykorzystaniem technologii informacyjno-telekomunikacyjnej stanowi istotną wartość ekonomiczną, 
społeczną i kulturową. Mimo prowadzonych badań i systematyzowania informacji na temat sektora ICT wciąż istnieje luka badawcza dotycząca jego znaczenia na arenie międzynarodowej. Powstaje zatem pytanie, jaki wpływ na zrównoważony rozwój ma występowanie klastrów sektora ICT w krajach Unii Europejskiej? Było to przesłanką podjęcia badań umożliwiających określenie stopnia znaczenia sektora w krajach UE. Punktem wyjścia rozważań było zdefiniowanie technologii informacyjno-komunikacyjnej i klastrów. Do oceny sektora wykorzystano: wskaźnik lokalizacji (LQ), wskaźnik specjalizacji (SI) oraz indeks klastra (CI). W wyniku przeprowadzonych badań wskazano czynniki decydujące o wzroście znaczenia sektora w krajach UE.

SŁowA KLUCZOWE: sektor ICT, produkcja ICT, usługi ICT, klastry, Unia Europejska.

\section{Summary}

For many years, the changes taking place in society and the economy have clearly been global. Information and communication technologies (ICT) contribute to these changes and are reflected in the products and services offered. ICT companies are rapidly adapting to the new conditions and requirements of the information society, where information processing using information and telecommunications technology is an important economic, social and cultural value. Despite research and systematisation of information on the ICT sector, there is still a research gap concerning its international relevance. The question therefore arises: what impact does the presence of ICT clusters in the Countries of the European Union have on sustainable development? This was a prerequisite for conducting research to determine the importance of the sector in EU countries. The starting point of the deliberations was the definition of information and communication technologies and clusters. Location index (LQ), specialization index (SI) and cluster index (CI) were used to assess the sector. The research identified the factors determining the growth of the sector in the countries of the European Union.

KEYwords: ICT sector, ICT production, ICT services, clusters, European Union.

Nota o autorze

Magdalena Łada - mgr, Uniwersytet Warmińsko-Mazurski w Olsztynie, Wydział Nauk Ekonomicznych, Olsztyn; główne obszary działalności naukowej: ekonomia i finanse; e-mail: magdalena. lada@uwm.edu.pl; ORCID: 0000-0003-1171-284X. 